\title{
THEORETICAL AND EMPIRICAL ASPECTS OF BUDGET DEFICITS
}

\author{
Ramazan TAS ${ }^{*}$
}

\section{INTRODUCTION}

In recent years there has been major public concern about the government budget deficit. Is the ballooning budget deficit a serios economic problem? What are the theoretical explanations of the budget deficit (Standard, Ricardian, Neoclassical and Keynesian)? Is there any difference between tax induced and expenditure induced deficits? Haw can we measure real fiscal deficit (real deficit nominal deficit, structurel deficit cyclical deficit)? What is the Fiscal Illusion? What are the effects of budget deficit on macroeconomic variables (interest rates, public spending, private consumption, private investment, national income)? What are the policies recommended to reduce budget deficits? above.

In this study, I tried to find satisfactory explanations for all subjects mentioned

\section{BUDGET DEFICITS IN THEORY}

\section{THE STANDARD VIEW OF BUDGET DEFICITS}

In the standard model there is an assumption that the substitution of a budget deficit for current taxation leads to an expansion of aggregate consumer demand. In other words, desired private saving rises by less than the tax cut, so that desired national saving declines. In a closed economy, the expected real interest rate would have to rise to restore equality betwcen desired national saving and investment demand. The higher real interest rate crowds out invesument, which shows up in the long run as a smaller stock of productive capital. Therefore in the language of Franco Modigliani (1986) the public debt is an intergenerational burden that it leads to a smaller stock of capital for future generations ${ }^{1}$.

\footnotetext{
* Ankara Universitesi Siyasal Bilgiler Fakültesi, Araştırma Görevlisi

${ }^{1}$ Franco Modigliani, Arlie Sterling "Goverment Debt, Government Spending and Private

Sector Behavior: Comment" American Economic Review,1986, 76, pp:1168 - 1179.
} 
In an open economy, a smail country's budget deficits would have negligible effects on the real interest rate in international capital markets. Therefore, in the standard analysis, the home counry's derision to substitute a budget deficit for current taxes leads mainly to increased borrowing frc II abroad, rather than to a higher real interest rate. That is budget deficits lead to current siccount deficits. Expected real interest rates rise for the home country only if it is lavge inough to influence world markets or if the increased national debt induces foriegn lendirs to demand higher expected returns on this country's obligations. In any event, there is a weaker tendency for a country's budget deficits to crowd out its domestic investmin: in the short run and its stock of capital in the long run. However, the current ac:olinl deficits show up in the long run as a lower stock of national wealth and corresponding,ly higher claims by foreigners.

\section{THE RICARDIAN VIEW OF BUDGET DEFICITS}

In the Ricardian perspectivis, a deficit-financed cut in current taxes for a given path of government spending, leads 10 higher future taxes that have the same present value as the initial cut. This result follows from the government budget constraint, which equates total expenditure for each period (including interest rates) to revenues from taxation or other sources and the net issue cf interest-bealing public debt. It's clear that government spending must be paid for now or later, with the total present value of receipts fixed by the total present value of speriting. Hence, holding fixed the path of govemment expenditures and non-tax reveriues, a cut in today's taxes, must be matched by a corresponding increase in the presint value of future taxes.

Suppose now that houschiolits' demand for goods depends on the expected present value of taxes. That is, each hols:thold subtracts its share of this present value from the expected present value of incom s: 0 determine a net wealth position. Then fiscal policy would affect aggregate consumer demand only if it altered the expected present value of taxes. But preceding argumeall ivits that the present value of taxes would not change as long as the present value of spi:iding did not change. Therefore, the substitution of a budget deficit for current taxes ( $(r$ any other re-arrengement of the timing of taxes) has no impact on the aggregate demand :or goods. In this sense, budget deficits and taxation have equivalent effects on the t:sonomy (Ricardian Equivalence Theorem). To put the equivalence result another wiay, $\hat{c}$ decrease in the government's saving (that is, a current budget deficit) leades to an offset:xng increase in desired private saving, and to no change in desired national saving. since c.esired national saving does not change, the real interest rate does not have to rise in a s:losed economy to maintain balance between desired national saving and invistment Jienand. Hence there is no effect on investment, and no burden of the public debt. In a solting of an open economy there would also be no effect on the current-account balance bicause desired private saving rises by enough to avoid having to borrow from abroad. Th sefefore, budget deficits would not cause current account deficits.

There are five major the Jictical objections that have been raised against the Ricardian Conclusions ${ }^{2}$ :

\footnotetext{
${ }^{2}$ Robert J. Barro "The Rizardian 'a pproach to Budget Deficits" TJOEP Spring. pp. 37 - 55.
} 
A) FINITE HORIZONS: People do not live forever and hence do not care about taxes that are levied after their death. Individuals capitalize only the taxes that they expect to face before dying. Hence the net wealth of persons currently alive rises and households react by increasing consumption demand. Thus as in the standard approach, desired private saving does not rise by enough to offset fully the decline in government saving.

B) IMPERFECT LOAN MARKETS: Ricardian Equivalence also fails because of imperfect credit markets. The government implicitly guarantees the repayment of loans through its tax collections and debt payments. Thus loans between people with good access and people with poor access take place even such loans were not viable (because of Transaction Costs) on the imperfect private credit market.

C) UNCERTAINITY ABOUT FUTURE TAXES AND INCOMES: The uncertainity about individuals' future taxes or the complexity in estimating them implies high rate of discount in capitalising these future liabilities. Therefore a substitution of a budget deficit for current taxes raises net wealth. Because the present value of the higher expected future taxes falls short of the current tax cut. It then follows that budget deficit raises aggregate consumer demand and raduces desired national saving. As a result, desired national saving tends to raise with a budget deficit if this uncertainity increases and vice versa.

D) THE TIMING OF TAXES: If taxes are not lump sum, for example with an income tax, budget deficits change the timing of income taxes and thereby affect people's incentives to work and produce in different periods. It follows that variations in deficits are non-neutral although the results tend also to be inconsistent with the standard view.

E) FULL EMPLOYMENT AND KEYNESIAN CASES: A common argument is that the Ricardian results depend on "full employment" and surely do not hold in Keynesian models. In Keynesian analysis if everyone thinks that a budget deficit makes them wealthier, the resulting expansion of aggregate demand raises output and employment and thereby actually makes people wealthier. (This result holds if the economy is in a state of "involuntary unemployment").

\section{THE NEOCLASSICAL VIEW OF BUDGET DEFICITS}

The Neoclassical model has three central features. Each of them plays an important role in determining the impact of budget deficits ${ }^{3}$.

a. The consumption of each individual is determined as the solution to an intertemporal optimization problem, where both borrowing and lending are permitted at the market rate of interest.

b. Individuals have finite lifespans. Each consumer belongs to a specific cohort or generation and the lifespans of successive generations overlap.

c. Market clearing is generally assumed in all periods.

${ }^{3}$ B. Douglas Beriheim "A Neoclassical Perspective on Budget Deficits" TJOEP. Spring. 1989, pp.57 - 60 . 
There is now a large literature that investigates the empirical validity of the first feature. Consumers behave as th (ugh they solve an intertemporal optimization problem with access to perfect capital ma:kets (King, 1983) and (Hayashi, 1985). Much of this literature builds upori Hall's (1578) formulation of the stochastic permanent income hypothesis. Despite numerous problems with estimation and interpretation, the evidence on balance supports the view that a sizable minority (roughly $20 \%$ ) of individuals fails to behave in a way that is consist:mt with unconstraint intertemporal optimization.

In the case of some liquidity constrained or myopic consumers, this would not alter the conclusion that a permanent rorease in the ratio of debt to national income depresses capital accumulation. Permanent deficits redıce the interest sensitivity of savings and larger increases in interest rates are: required to equilibrate capital markets. Accordingly, the introduction of liquifity consilained consumers might well strengthen the conclusion that permanent deficits depress cilyital accumulation.

On the other hand, in the cas: of liquidity constrained individuals, temporary deficits will have immediate and substantial negative effects on the savings. Because for the constrained individuals, the marg!inal propensity to consume out of liquid resources is unity.

The second characteristic (fivite lifespans) defines the central difference between the Neoclassical and Ricardian frameviorks.

The third characteristic (fil.:. employment) is the primary distinction between the Neoclassical and Keynesian paradi !ms.

It's useful to summarize the main empirical implications of Neoclassical view of budget deficits:

If consumers are rational, fat:ighted and have access to perfect capital markets, then permanent deficits significantly clippress capital accumulation and temporary deficits have either a negligible: or perversi: effect on the most economic variables (including consumption, savings ard interesil rates).

If many consumers are either liquidity constrained or myopic, the impact of permanent deficits remains quali ativly unchanged. However temporary deficits should depress savings and raise interes 1 tates in the short run. Thus the Neoclassical paradigm does not tie down the effects of te:nporary defncits, and evidence that bears on the effects of temporary deficits is not useful for testing this paradigm. It's clear that the fundamental lessons of the P $\mathrm{Vec}$ :lassical framework concem the effects of permanent deficits.

\section{THE KEYNESIAN VIEW OF BUDGET DEFICITS}

The Keynesian view differs: from the Neoclassical paradigm in two fundamental ways.

1. It allows for the possibility that some cconomic resources are unemployed. 
2. It presupposes the existance of a large number of myopic, liqudity constrained individuals. This second assumption guarantees that aggregate consumption is very sensitive to changes in disposable income ${ }^{4}$.

In the simplest and most naive Keynesian model, increasing the budget deficit by $1 T L$ causes output to expand by the inverse of the marginal propensity to save. In the standard IS-LM analysis of monetary economies, this expansion of output raises the demand for money. If the money supply is fixed (that is the deficits is bond financed), interest rates must rise and private investment falls. This in turn raduces output and partially offsets the Keynesian multiplier effect.

Many uaditional Keynesians argue that deficits need not crowd out private investment. Eisner suggests that increased aggregate demand changes the profitability of private investment and leads to a higher level of investment at any given rate of interest. Thus deficits may actually stimulate aggregate saving and investment despite the fact that they raise interest rates. In Eisner's view, increased consumption is supplied from otherwise unutilized resources 5 .

Two major objections may be raised to the Keynesian theory of budget deficits:

a) The Keynesian outlook on budget deficits presupposes that the government can and will "fine tune" fiscal policy. If we grant that deficits stimulate aggregate demand, it follows that there are circumstances in which this stimulation may be detrimental. Even the most steadfast Keynesian is willing to concede that at full employment real deficits crowd out private investment and raise the rate of inflation.

Recognising the real cost of crowding out, many Keynesians (such as Eisner) argue for a policy of "nominal deficits", which would preclude real deficit from rising once the economy achieved full employment. This policy would channel all the effects of inappropriately timed deficits into inflation. Advocates of this strategy apparently adopt the purist view that "Inflation is costless". The experience of 1970 s strongly suggests otherwise. Inflation interactes with the tax system to produce significant distortions of behavior. It often redistribute resources in undesirable directions. In addition higher rates of inflation are associated with greater price variability. Formal models of price adjustment suggest a causal relationship. Thus inflation adds significant randomness and uncertainity to the economic environment. If Keynesian analysis implies that deficits can have either positive or detrimental effects then the proper management of fiscal policy becomes critical.

b. Keynesian view primarily describes the effects of temporary deficits. Indeed it is essentially compatible with the Neoclassical paradigm which primarily concerns the effects of parmanent deficits.In failing to distinguish between temporary and permanent deficits, Keynesians provide misleading advice to policy makers 6 .

${ }^{4}$ B. Douglas Bernheim, op. cit. pp. $60-63$.

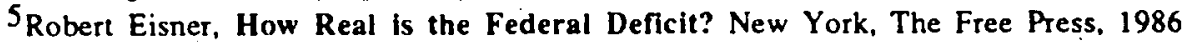

${ }^{6}$ B. Douglas Bernheim, op. cit. pp. $60 \cdot 61$. 


\section{MACROECONOMIC IMPACTS OF BUDGET DEFICITS}

Under some simplifying assurnptions we can examine the both cases of tax induced deficits and expenditure induced delicits. Here are the assumptions?

In addition to the governmerl. sector we have a two-household economy, we also posit the existance of unemployel resources so some members. of the households are unemployed. Any debt in pericid cil $:$ must be redeemed in period two. Perfect knowledge and ultrarational behaviour upon the part of the private sector. An initial equilibrium position with both government out $\mathrm{e} y \mathrm{~s}$ and tax receipts precisely balanced. The resulting budget deficit is financed by tind sales to the private sector with no prior debt outstanding.

\section{A MACRO EFFECTS CF TAX INDUCEI FISCAL DEFICITS}

For expositional purposes we assume goverrment outlays on goods and services are constant whereas taxes are endoger ous on income.

While the economy is in squilibrium level with income $Y 1$, interest rate $\mathrm{Il}$, and the balanced budget ( $\mathrm{G}-\mathrm{T}=\mathrm{O}$ ), if $\mathrm{g}, \mathrm{cv}$ ərnment cuts marginal rate of income tax, tax function pivots to Tposition and generates i: deficit equal to the amount $\mathrm{D}$ to be financed by bond sales to the private sector (sie: Taat. 1).

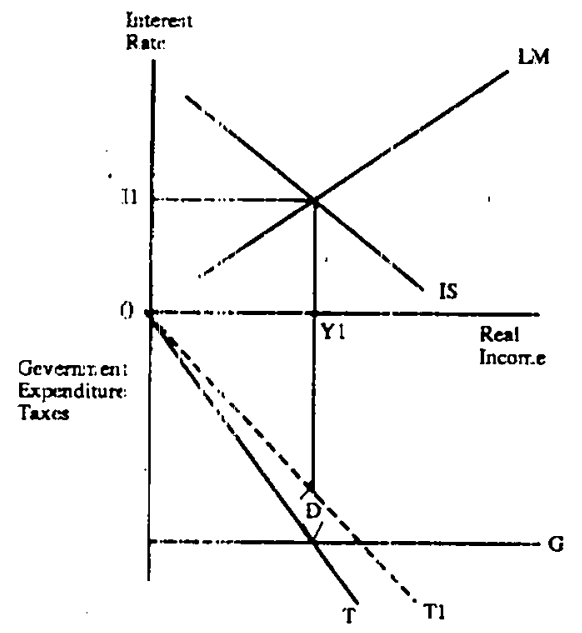

Does this tax-reduced operation cause any feedback effects upon IS-LM functions and are there any implications for the macroeconomy? In period 1. the private sector's tax burden falls by the amount $D$. $Z$ Ut at the same time the private sector gives up the

${ }^{7}$ G.K. Shaw, "Macroeconomic lraplications of Fiscal Deficits: An Expository Note". Scottish Journal of Political Economy, Vol. 34, No.2, May 1987, p. 193 
amount $\mathrm{D}$ to acquire an interest-bearing asset which finances the deficit. As a result at period 1 the disposable income of the private sector remains unchanged.

In period 2 the private sector will receive a cash amount equal to $D(1+I)$ when the debt is redeemed. On the other hand, the private sector with perfect knowledge and rational behaviour will notice that in period 2 it will be required to pay taxes equal to the amount $(D+I)$ to redeem and service the debt. Thus, the private sector's net position remains unchanged over the two periods in question and therefore there will be no any feedback on the initial IS-LM equations. Furthermore, this substitution of debt for taxes requires no change in the prevailing rate of interest because the ultrarational private sector will be indifferent to the actual interest rate changes. Whatever the rate, it will be necessary to meet the future tax obligation. Extending the analysis to an (n) period setting, it does not change this conclusion.

\section{B. MACRO EFFECTS OF EXPENDITURE INDUCED FISCAL DEFICITS}

While the economy is in equilibrium with income $Y 1$, interest rate $I 1$ and the budget precisely balanced $(\mathrm{G}-\mathrm{T}=\mathrm{O})$, let us assume that this equilibrium is disturbed by an increase in government expenditures which generates a budgetary deficit equal to the amount D. (see: Tab.2) What does it matter?

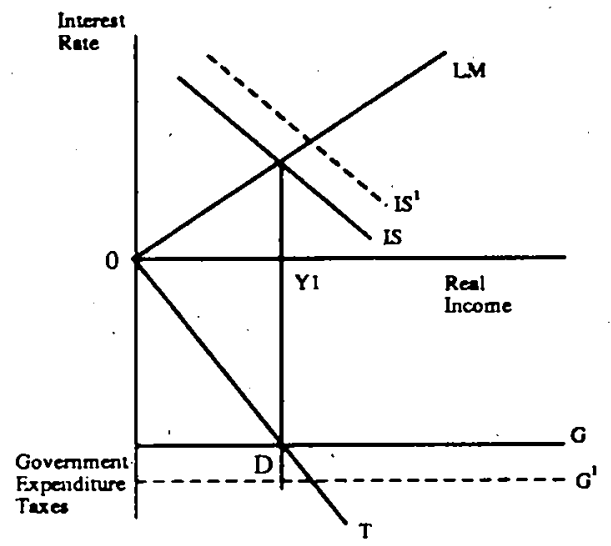

In period 1, while the private sector's disposable income is decreased by its take-up of government bonds equal to the amount $D$. Also its real disposable income is increased by the additional government provision of goods and services. but the net impact on the private sector will depend on the valuation it gives to the additional provision of goods and services.

In all cases where the marginal propensity to consume is less than one, expenditure induced deficits will cause an expansionary effect on the economy. It's clear that the effect will be greater, the greater the valuation given by the private sector to the additional provision of goods and services. In the real economic life it can be said that the private 
sector will probably give al posilive: valuation to the government provision of goods and services so that expenditure induce d deficits will cause to positive changes upon output, employment, interest rates and tix rields ${ }^{8}$.

\section{III- MEASURING THE BUDGET DEFICITS}

In order to talk about budgget di:ficits we must have an accurate measure of their size. But there are some fundamental protiterns of measuring deficits. Substituting depreciation for public investment expenditur:s, including state and local budgets in the deficit calculation and examining net natirial worth may solve of the problems.

I think that it's worth emphazing on the difference between real-nominal and structural-cyclical deficits.

\section{A. REAL DEFICITS - NOMINAL DEFIC:ITS}

We can consider the change in the real value of the net public debt as the sum of these three components 9 : liabilites.

1. The nominal deficit sxclusive of of setting changes in financial assets and

2. Changes in the nominal mizket value of existing financial assets and liabilities due to changes in nominal iriterest ctes. (inflation).

3. Changes in the real valus due to changes in the general level of prices

When we subtract these "irı:rest effects" and "price effects" from the nominal budget deficits, we get a neasure of the real deficits. The real deficit corresponds to the change in the real value of the riet government debt which should not be noted as nominal deficit divided by a price deflator. For this reason the real deficit may be very different from the nominal deficit tiat takes the all attention.

\section{B. STRUCTURAL DEFICITS - CYCLICAL DEFICITS}

It seems to be that present fiscal deficits are growing beyond the acceptance of cyclical deficits. If deficits were: inustly cyclical, they would grow in recessions and tum into surpluses during the recovery. This being the case, the public debt would not accumulate over time. But the pres:nt stuation seems to be different. Today's deficits are not cyclical but structural. Struitural deficits would remain "high" even if full employment is achived.

\footnotetext{
${ }^{8}$ G.K. Shaw, op. cií. pp. $197 \cdot 19 \mathrm{k}$

${ }^{9}$ Robert Eisner, "Budget [Deficits: Ithetoric and Reality" T.JOEP Vol.3, N. 2, Spring 1989, pp. 73.79 .
} 


\section{c) DEBT NEUTRALITY - DEBT NON-NEUTRALITY (FISCAL ILLUSION)}

DEBT NEUTRALITY : It means that "the issue of debt has similar effects to the raising of tax reveue". This hypothesis implies that when a government issues debt finance instead of tax finance, individuals must notice that additional future taxes will have to be raised in order to pay debt interest. The future taxes discounted at debt interest rate have an equal present value with taxes which might have been used to finance current expenditure so that timing of tax liabilities has a neutral effect on the wealth of the taxpayer (Ricardo. 1951: Barro, 1974) emphasised that neutrality rests on perfect foresight and complete information which no taxpyer can reasonably posses. Even if he could forecast accurately the timing of the debt interest changes resulting from debt issue now in place of taxes, his wealth position might be altered if the tax system embodied distributional elements (Carmichael, 1972) ${ }^{10}$.

\section{DEBT NON-NEUTRALITY (FISCAL ILLUSION) :}

In the recent literature of public choice, fiscal illusion is considered to depend mainly upon the cost of obtaining accurate information on the individual fiscal burden. It's also claimed that these costs are likely to vary according to the different kinds of public revenue and the structure of the revenue system. Thus a comman explanation for the differental growth of public spending follows the line of argument that the differential dependes on the degree of elasticity of the tax structure (Craig and Heins, 1980) ${ }^{11}$.

It can be said that there is less resistance to spending when tax yields can increase without any alteration in rates of tax.

Another argument stresses that information costs vary with the complexity of the tax structure. Individuals notice the costs of government services to be lower under a system relying on many tax sources than under a system depending heavily on a source of revenue (Pommere and Schneider. 1978) ${ }^{12}$.

A natural extension of the fiscal illusion approach beyond tax revenue must be the (tax / debt) ratio. Hence Buchanan-Wagner Hypothesis states that a replacement of current tax financing by government borrowing has the effect of reducing the noticed price of public goods and services. Because taxpayers do not fully anticipate the future tax liability implied by borrowing. Accordingly taxpayers underestimate the price of publicly-provided goods and services, therefore the demand for them increases. Taking all of these into account, it does not seem to be any a priori reason why debt-propelled public spending should be a permanent phenomen with voters consistently misnoticing both the total and marginal costs of taxes imposed on them (for example, Gandenberger,

10J. Carmichael, "On Barro's Theorem of Debt Neutrality: The Irrelevance of Net Wealth" The American Economic Review, Vol. 72, 1972.

${ }^{11}$ E.D. Craig, A.J Heins, "The Effects of Tax Elasticity on Govemment Spending". Public Choice, Vol. 9, 1980.

12W. Pommerehne, F. Schneider, "Fiscal Illusion Political Institutions on a Local Public Spending", Kylos Vol. 31 . 
1986.) ${ }^{13}$. Yet this permanent state of illusion is important if the level of public spending, far less its growth, is to tw: significantly affected.

\section{IV- RELATIONS BETWEN BUDGET DEFICITS AND MACREOCONOMIC VARTA.TBLES}

\section{BUDGET DEFICITS - INTEREST RATES}

Richard J. Cebula studied to examine the interest rate impact of the structural budget deficits instead of simply lite total budget deficits. He estimates reduced-form equations and suructural equations using annual data for the United States during (19551984). The model used by him allows for international capital flows and inflationary expectations. The finding is that fediral budget deficits exercise positive and significant impact upon a variety of interest ratis: 14 .

\section{THE MODEL:}

The nominal rate of interes $\mathrm{S}$. alas been regarded as being determined by a lonable funds equilibrium of the following from:

$$
\begin{aligned}
& \mathrm{D} \cdot \mathrm{S}=\mathrm{B}-\mathrm{M} \text { (1) D: real private sector bond demand. } \\
& \mathrm{D}=\mathrm{D}(\mathrm{R}, \mathrm{P}) \\
& S=S(R, P, P C Y) \\
& \text { (2) M: real purchases of securities by the government } \\
& B \text { : real borrowing by the government. } \\
& \text { (3) R: nominal rate of interest } \\
& P \text { : expected future inflation. } \\
& \text { PCY: the change in per capita real GNP, } \\
& R=R(P, P C Y, E, M) \quad \text { (4) SD: the real structural budget deficit. } \\
& \text { (Dr>O. Ip }<\text { O. Sr<O. Sp>O. Spcy>O.) } \\
& R=R(P, P C Y, S D, M) \quad(5) \quad(R p>0 . R . p c y>0 . R s d>0 . R m<0 .)
\end{aligned}
$$

Using this model, he initially titimated the following reduced-form equation:

$$
\mathrm{Rt}=\mathrm{aO}+\mathrm{al}^{*} \mathrm{Pl}+\mathrm{a}^{\prime}{ }^{*} \mathrm{FC}^{\prime \prime} \mathrm{r}+\mathrm{a} \mathbf{3}^{*} \mathrm{SD}+\mathrm{a}^{*} \mathrm{M}+\mathrm{U}^{\prime}
$$

Richard J. Cebula estimates th:s model and find that structural deficit variable (it's the difference between the: lotal deficit and cyclical deficit. It's also the exogenous component of the total deficit) is pusitive and statistically significant at the one per cent level. Thus it appears that the siunctural deficit exercises a positive and significant influance upon the nominal rate of interest

\footnotetext{
${ }^{13} \mathrm{O}$. Gandenberger, "On Governunent Borawing and False Political Feedback" Publlc Finance and Public Dett. Detrot. 1986 pp. 205 - 16.

${ }^{14}$ Richard J. Cebula, "An Empirical Analysis For The United States" 1955-1984, Public Finance, V. 43, No. 3, 1988 pp. 3.17 - 347.
} 
On the other hand, there are a lot of study which find that budget deficits have no measurable impact upon interest rates (Evans, 1985,1987, Hoelscher, 1983, Motley, 1983, Mascaro and Meltzer, 1983).

The difference between the findings here and the findings in those other studies can be traced to the way in which how specified the deficit variable as structural one or total one.

From another respect, in accordance with the Domar Model, the ratio of interest paymants to GNP will not converge if present rates of economic growth or interest rates continue. This being the case, it may be argued that a big debt at present would eventually bancrupt the government. When fiscal deficits accumulated, cause a heavy burden on the budget by interest rates on national bonds. However the sharp rise in interest payments caused by an accumulating national dond causes serious problems in the performance of government fiscal activity. Large increases of national bonds may make interest payments faster growing component of public expenditure. It appears that fiscal deficits are feeding upon themeselves through the interest component of public expenditures.

\section{BUDGET DEFICITS - PUBLIC SPENDING}

There are three important studies to examine the role of public debt as a causal factor of public expenditure growth:

1. The first study is made by Niskanen. He concludes that "public deficits significantly-increase total-public spending. The increasing proportionate deficits during the last decade have significantly increased the rate of growth of real public spending" 15 . But there are a lot of objections against Niskanen's methodology in respect to used econometric method.

2. The second hypothesis has been made by Shibota and Kimura. They propose that "a revenue increase and spending increase occur simuitaneously, implying that an automatic revenue increase resulting from economic growth and inflation under a progressive tax structure will be the main factor governing public expenditure growth. This hypothesis is consistent with Japanese but not with American data (Shibata and Kimura, 1986) ${ }^{16}$.

3. The third approach consideres the role played by unfunded obligations of government. The most striking example of such obligations is to be found in future pension payments in state retirement schemes. Such obligations are noticed to be accumulated assets by contributors to state pensions and therefore affect their economic behaviour in various ways, notably through their savings decisions.

15 W. A. Niskanen, "Deficits, Government Spending, and Inflation: What is the Evidence?" JOME, V. 4, No. 3, pp. $591-602$

${ }^{16} \mathrm{H}$. Shibata, Y. Kimura, "Are Budget Deficits the Cause of Growth in Government Expenditures?"in Bernard P. Herber, 1986, pp. 229 - 42. 
In addition (Boskin. 1982) estimated that the deficil derived from unfunded pension obligations in real 1980 disccunted dollars was twice the U.S. federal debt as conventionally measured. Lik:ewi:ie (Hills, 1984) estimates for the U.K. a figure which is three times the British national dr:bt ${ }^{17}$.

The discussion of the corcept of unfunded obligations seems to support the hypothesis that the growth of public spending in the long term can be markedly influenced by debt propulsion. Tre possibility of increasing unfunded obligations reduces the noticed price not of present $k$ II future public expenditure.

There is another empirical svidence that supports the theoretical proposition put forward by Buchanen-W/agner. This "government deficits increase the level of public spending" view has been examimed by Ashfaque $H$. Khan for Pakistan, a developing country. He finds that the estimaled tax-price elasticity of demand for public goods for Pakistan is much higher than the one reported by Provopoulos (1982) for Greece and it's also higher than the one reported by Niskanen (1978) for the U.S.A. This finding confirms the dominant role of public sector in a developing country ${ }^{18}$.

\section{BUDGET DEFICITS - PRIVATE CONSUMPTION}

Two valuable studies must $w$ taken into account about this subject:

The fist is made by (3errheim, 1987) using cross-country data relate average consumption to averge deficils yer six years and twelve years period. The second is made by (Reid, 1985) alsc using multiple year averages in a study of the U.S.A. experience. These papers are notable in that they represent attempts to measure the impact of permanent deficits.

Both Bernheim and Reisl found that permanent deficits significantly raise consumption as a fraction of rational income 19 .

These results are consistent with the Necclassical Paradigm.

\section{BUDGET DEFICITsi - PRIVATE INVESTMENT}

The extent to which the pul:lic debt issued to finance budget deficits will crowd out private investment will depenc on the rate of saving of the country. A country with a high rate of saving that excreds its domestic investment opportunity can easily finance its own investment as well as its: fiscal deficits. But this is to be contrasted with not high enough rate of saving and where an increasing share of savings has been appropriated to fiscal dericits.

17J. Hills, "What is the Public SE:tor Worth?" Fiscal Studies Vol. 5. No. 1, 1984.

${ }^{18} \mathrm{H}$. Ashfague Khan, "Public Spending and Deficits: Evidence from a Developing Country", Public Finance, V. 43. No. 3. 1988, pp.396 - 401.

19 A. Peacock, I. Rizzo, "Government Debt and Growth in Public Spending" Public Finance, V. 42, N. 2 1987, pp.282 - 291. 


\section{BUDGET DEFICITS - NATIONAL INCOME (OUTPUT)}

The relationship between budget deficits and national income has been studied most extensively by Eisner. Eisner's view is that "the data strongly support the Keynesian view so deficits significantly stimulate aggregate economic activity.

If there is no involuntary unemployment and there are no idle resources, increased demand caused by budget deficits can not generate more output, it can only bring higher prices. This is apparantly the world of Milton Friedman and Lucas, although they allow for various short run real effects as economic agents are slow or asymmetrical in their assimilation of information.

But in the case of unemployment and idle resources, real structural budget deficits will stimulate the output ${ }^{20}$.

\section{V- CONCLUSION}

Since recent deficits are largely structural, they have to be reduced through basic changes at the level and pattern of public expenditures and in the tax system.

In the case of structural deficits, it seems to be that a Keynesian type of policy can not be any help in reducing fiscal deficits. Keynesian policies are merely temporary stopgap measures. Needless to say, stop-gap measures help in reducing debt accumulation, but they do not bring a permanent solution to the fiscal unbalance. It's clear that permanent solutions require permanent measures. Structural reforms become necessary when debt accumulation results from structural deficits 21 .

Keynesian policies may be able to bring some short-run reductions of the public debt by natural increases of taxes generated by a higher rate of growth. Besides they will not cure the disease of debt accumulation. Furthermore, we must note that the economic realities may dictate there would be no more continued expansion of business. Given such future performance of the economy, tax revenues on a scale large enough to reduce automatically the accumulation of public debt can not be expected.

It's offered two policies of reducing budget deficits:

\section{CEILING METHOD}

On this point a new strategy of "administrative reform" can be highly evaluated as a proper policy choice. The government may intend to contain the size of fiscal deficits by expenditure cuts rather than tax increases. The government must cut inefficient and unnecessary components of public expenditures. A slogan of "fiscal reconstruction without any tax increases" may be followed by the government. For this reason the government may set a "maximum level" for requiring increases in public expenditures

${ }^{20}$ Robert Eisner, "Budget Deficits: Rhetoric and Reality" TJOEP, Vol. 3, N. 2, Spring 1989. pp. $81-82$.

21 Hiromitsu Ish, "Overview of Fiscal Deficits in Japan With Special Reference to the Fiscal Policy Debate", Hitotsubashi Journal of Economics, 27 (1986) pp. 133 - 148. 
relative to the previous year. The ceiling gradually turns into zero or minus in specific budget items. As a result, it takes the form of excluding various categories of expenditures which more come:-ily should be assigned to the general account budget. Thus fiscal authority would te successful in obscuring its true expenditure position and covering the impression of adhe:ence to "fiscal reconstuction with expenditures cuts" to the public 22 .

\section{A TAX' POLICY WITH a CONSTANT RATIO OF TAX} BURDEN RELATIVE TO NATIONAL INCOME AND INTENDED UNDERESTIMATION CH THE NATURAL INCREASES IN TAX YIELDS CAUSED BY A IROWING ECONOMY

Keeping the ratio of tax yields to the national income constant leads to large amounts of tax reductions in ai growing economy. In particular the personal and corporate income taxes must sigrificartly be reduced every year. If tax reductions had not been implemented income taxation would have cosiderably overburdened the taxpayers. Therefore to avoid overburden.r.g the taxpayers, the income taxes had to be reduced successively almost every year 'That's to say, one portion of the natural tax increases must be appropriated 1.0 the fillancing of tax reductions. The other portion must be devoted to the financing of rievi expenditures programs. Thus a big expansion-minded budget will be created by mearısi of such large amounts of natural increases in tax yields causing no problem of riscal dc icits. A question may be raised about the estimation of the natural tax increase. It would largely be based on the anticipated rate of economic growth which is usually compured five or six months earlier than the begining of fiscal year. Since at the end of each ft:cal year the realised rate of growth will always be much higher than the anticipated rale, an enormous natural increase in tax yields will exist during the intermediate term after the inplementation of the new budget. As a consequence the govemment wald not need to issue national bonds and would be able to sustain budgetary balanice ${ }^{23}$

${ }^{22}$ Hiromitsu Ishi, op. cit. p. 1.45 .

${ }^{23}$ Hiromitsu Ishi, op. cit. p. $1+73$. 


\section{REFERENCES}

Barro J. Robert, (1989) "The Ricardian Approach to Budget Deficits". The Journal of Economic Perspectives (TJOEP) Vol. 3, N. 2 Spring, pp. 37-55.

Bernheim B. Douglas, (1989) "A Neoclassical Perspective on Budget Deficits" TJOEP. Vol. 3, N. 2 Spring, pp. 55-73.

Cebula J. Richard, (1988) "Federal Government Budget Deficits and Interest Rates: An Empirical Analysis for the United States. 1955-1984", Public Finance, Vol. 43, N. 3 pp, 337-349.

Dalamagas A. Basil, (1987) "Government Deficits, Crowding out and Inflation: Some International Evidence", Public Finance, pp. 65-85.

Eisner Rober, (1989) "Budget Deficits: Rhetoric and Reality" TJOEP, Vol. 3, N. 2 Spring. pp. 73-95.

Gramlich M. Edward, (1989) "Budget Deficits and National Saving: Are Politicians Exogenous?" TJOEP, Vol. 3, No. 2 Spring, pp, 23-37.

Ishi Hiromitsu, (1986) "Overview of Fiscal Deficits in Japan..." Hitotsubashi Journal of Economics, Vol. 27 pp. 132-148.

Khan H. Ashfague, (1988) "Public Spending and Deficits: Evidence from a Developing Country", Public Finance, Vol. 43, No. 3 pp. 396-403.

Kimura Yoko and Shibata Hirofumi, (1987) Government Debt and Growth in Public Spending; A Reply" Public Finance, pp. 292-297.

Peacock Alan and Rizzo Lide, (1987) "Government Debt and Growth in Public Spending" Public Finance, Vol. 42; No. 2 pp. 283-292.

Shaw K. G., (1987) "Macroeconomic Implications of Fiscal Deficits" Scottish Journal of Political Economy, Vol. 34; No. 2 pp. 192-199.

Yellen L. Jenet, (1989) "Symposium on the Budget Deficits" TJOEP, Vol. 3, No.2 Spring, pp. 17-23. 